\title{
Experimental Study on Treatment of Ballast Water by Inert Flue Gas Deoxidation
}

\author{
Guozhi Bao \\ School of Energy and Power, Jiangsu University of Science and Technology, Zhenjiang, China, gzbao2015@163.com \\ Peng Yang \\ School of Energy and Power, Jiangsu University of Science and Technology, Zhenjiang, China \\ Rui Da \\ School of Energy and Power, Jiangsu University of Science and Technology, Zhenjiang, China \\ Junxia Li \\ School of Energy and Power, Jiangsu University of Science and Technology, Zhenjiang, China \\ Guanghui Zhao \\ School of Energy and Power, Jiangsu University of Science and Technology, Zhenjiang, China
}

See next page for additional authors

Follow this and additional works at: https://jmstt.ntou.edu.tw/journal

Part of the Fresh Water Studies Commons, Marine Biology Commons, Ocean Engineering Commons, Oceanography Commons, and the Other Oceanography and Atmospheric Sciences and Meteorology Commons

\section{Recommended Citation}

Bao, Guozhi; Yang, Peng; Da, Rui; Li, Junxia; Zhao, Guanghui; and Chen, Ning (2021) "Experimental Study on Treatment of Ballast Water by Inert Flue Gas Deoxidation," Journal of Marine Science and Technology. Vol. 29: Iss. 3, Article 1. DOI: $10.51400 / 2709-6998.1430$

Available at: https://jmstt.ntou.edu.tw/journal/vol29/iss3/1

This Editorial is brought to you for free and open access by Journal of Marine Science and Technology. It has been accepted for inclusion in Journal of Marine Science and Technology by an authorized editor of Journal of Marine Science and Technology. 


\section{Experimental Study on Treatment of Ballast Water by Inert Flue Gas Deoxidation}

Authors

Guozhi Bao, Peng Yang, Rui Da, Junxia Li, Guanghui Zhao, and Ning Chen 


\title{
EDITORIAL
}

\section{Experimental Study on Treatment of Ballast Water by Inert Flue Gas Deoxidation}

\author{
Guozhi Bao, Peng Yang, Rui Da, Junxia Li, Guanghui Zhao, Ning Chen* \\ School of Energy and Power, Jiangsu University of Science and Technology, Zhenjiang 212003, China
}

\begin{abstract}
In this paper, the antimicrobial effect of inert flue gas on indicator microorganisms in ballast water was investigated based on a $265 \mathrm{~h}$ test. The inert flue gas consists of nitrogen $\left(\mathrm{N}_{2}\right)$ and carbon dioxide $\left(\mathrm{CO}_{2}\right)$ the microorganisms include Chlorella and Escherichia coli. Within the scope of the test, the killing effect of the microbes treated by combining $\mathrm{N}_{2}$ and $\mathrm{CO}_{2}$ was higher than that of using only either $\mathrm{N}_{2}$ or $\mathrm{CO}_{2}$. When the dissolved oxygen concentration in the ballast water was $0.5 \mathrm{mg} / \mathrm{L}$ and the $\mathrm{pH}$ value was 6 , the killing effect was the highest. At this time, the mortality rate of Chlorella sp. and $E$. coli reached $99.99 \%$, and $99.98 \%$, respectively. After the experiment, property of the ballast water treated by $\mathrm{N}_{2}$ and $\mathrm{CO}_{2}$ were analyzed. The dissolved organic carbon concentration was lower than the recommended minimum concentration of $5 \mathrm{mg} / \mathrm{L}$. The concentration of particulate organic carbon was higher than the standard value of $0.3 \%$.The experiment proposes a new method for ballast water treatment of large ocean-going vessels in the future.
\end{abstract}

Keywords: Ballast water, Inert flue gas, Water treatment, Chlorella

\section{Introduction}

$\mathrm{T}$ he ballast water loaded by large ocean-going vessels in a port is likely to cause invasion of alien species when it unloaded in another port. It may cause devastating impacts on other species, and cause serious damage to the local ecological environment [1]. To prevent ecological disasters caused by ballast water unloaded, the International Maritime Organization (IMO) has developed the International Convention for the Management and Control of Ships' Ballast Water and Sediments. It is stated clearly that the discharge of ballast water must meet the ballast water treatment performance standard (D-2 standard) and it was officially implemented in September 2017 [2,3].
At present, the ballast water treatment has attracted the attention of the international community and many scholars. Treatment methods mainly include mechanical [4], physical $[5,6]$ and chemical [7] treatments. Guilbaud et al. [4] evaluated the economic feasibility of membrane treatment for ballast water. Bradie et al. [6] used a variety of detection methods to investigate the microbial survival after filtration and ultraviolet (UV) rays treatment. Zhang et al. [8] studied the synergistic killing effect of ozone and $\mathrm{H}_{2} \mathrm{O}_{2}$ on $E$. coli. These methods can effectively kill planktonic microorganisms in ballast water and prevent biological invasion during transportation. In addition to the high cost, these methods may also cause corrosion of the ship's cabin, which has potential hazards for the safe operation of the ship and cause secondary invasion of organism [9-11]. Other authors have proposed deoxidation treatment of ballast water to kill planktonic microorganisms, and achieved some

Received 23 July 2019; revised 17 June 2020; accepted 28 July 2020.

Available online 25 June 2021.

* Corresponding author. 666 Changhui Road, Dantu District, Zhenjiang City, Jiangsu Province, China.

E-mail address: gzbao2015@163.com (G. Bao). 
positive results. McCollin et al. [12] added nutrients to ballast water to promote bacterial growth, thereby creating an anoxic environment; the number of zooplankton in the ballast tank was dramatically reduced after 5 days. It was due to the fact that aerobic and facultative anaerobic bacteria died and replaced by obligate anaerobic bacteria. However, the killing effect on phytoplankton was not obvious. Lafontaine et al. [13] evaluated the effectiveness of yeast deoxygenation process on ballast water treatment in the cabin at $4-25{ }^{\circ} \mathrm{C}$. The test environment reached full deoxidation conditions $(0.3 \mathrm{mg} / \mathrm{L})$. The results showed that this method could effectively eliminate a large number of aquatic organisms, but the effect on viruses, bacteria and even some phytoplankton needed to be further studied. The authors further investigated the treatment effect of the yeast deoxidation process on cabin ballast water below $1.5^{\circ} \mathrm{C}$ [14]. The results show that biological deoxygenation at low temperatures will not increase toxic substances in the ballast water. The increased concentration of ammonia, organic carbon and particulate matter produced during the treatment of ballast water by the yeast deoxygenation process may have adverse environmental effects. Tamburria et al. [15] found that the use of nitrogen to remove oxygen from ballast water tank could reduce corrosiveness of the ship and had a good killing effect on aerobic species. However, some facultative anaerobic strains were capable of multiplying in deoxygenated ballast water.

The existing research generally concerns preventing the risk of biological invasion during loading and unloading of ship's ballast water to meet international emission standards. Although the deoxidation treatment of ballast water has gradually attracted the attention, experimental data is still relatively scarce. In order to provide more valuable experimental data of deoxygenation treatment of ballast water, it is proposed to use the inert flue gas (nitrogen $\left(\mathrm{N}_{2}\right)$, carbon dioxide $\left(\mathrm{CO}_{2}\right)$ and oxygen $\left.\left(\mathrm{O}_{2}\right)\right)$ in the exhaust gas of marine diesel engines to treat ship ballast water. During ship's navigation, a large amount of flue gas is emitted; after desulfurized and denitrified, the oxygen content of the flue gas is generally lower than $0.5 \mathrm{mg} / \mathrm{L}$, which is regarded as a good inert flue gas. In this paper, the killing effect of the inert flue gas deoxygenation method on Chlorella sp. and E. coli (index microorganisms) in the ballast water was investigated. Chlorella sp. is a unicellular green alga, a spherical single-celled freshwater algae and a common algae in the sea. Escherichia coli is bacteria in the intestines of humans and animals. E. coli is a proteobacteria that can produce vitamins which are beneficial to humans and animals.

\section{Experimental system and operating procedures}

\subsection{Experimental system}

The experimental system mainly included the inert flue gas generation system, the gas-liquid mixing system, the pumping system, the piping system, the analog ballast tank system and some accessories, as shown in Fig. 1. The ballast tank was made of stainless steel with a size of $0.5 \mathrm{~m} \times 0.5 \mathrm{~m}$ $\times 0.5 \mathrm{~m}$ and a thickness of $3 \mathrm{~mm}$. The amount of water in the test was 100L. The inert flue gases were high purity $\mathrm{N}_{2}$ and/or $\mathrm{CO}_{2}$. A horizontal centrifugal pump with a rated flow of $1.5 \mathrm{~m}^{3} / \mathrm{h}$ is used as analog ballast pump. The gas flow was regulated by a seven-star mass flow controller. The simulated inert flue gas and ballast water were mixed in a venturi to form a high pressure water flow and the inert flue gas formed the gas cavity in the water. The dissolved oxygen was drawn into the gas cavity and then overflowed from the water, which changed the ballast water environment. The venturi ejector mixed with the simulated inert flue gas with seawater [16]. The function of the breathing valve on the simulated ballast tank was to maintain a slightly positive pressure. In order to ensure that the partial pressure of the inert flue gas was higher than the pressure of the dissolved oxygen in the ballast water, the dissolved oxygen in the ballast water should be overflew. The dissolved oxygen concentration was detected using the on-line dissolution tester, and the $\mathrm{pH}$ value was measured by a $\mathrm{pH}$ meter. The indicator Chlorella sp. and E. coli were detected by a spectrophotometer and a colony counter, respectively. Sampling tests were conducted in $265 \mathrm{~h}$ for treatment and control of ballast tank. After the experiment, the pipeline was cleaned with water.

\subsection{Operation steps}

The following procedures were to ensure that the test equipment was connected correctly and the test system was airtight. The ballast water tank breathing valve and ballast tank drain pump were opened while starting the simulated inert flue gas mass flow controller and ballast water supply pump. After the ballast water supply flow rate was stabilized, the ballast tank breathing valve and the ballast tank drain pump were closed immediately. During the test, the water level for the ballast water tank and 


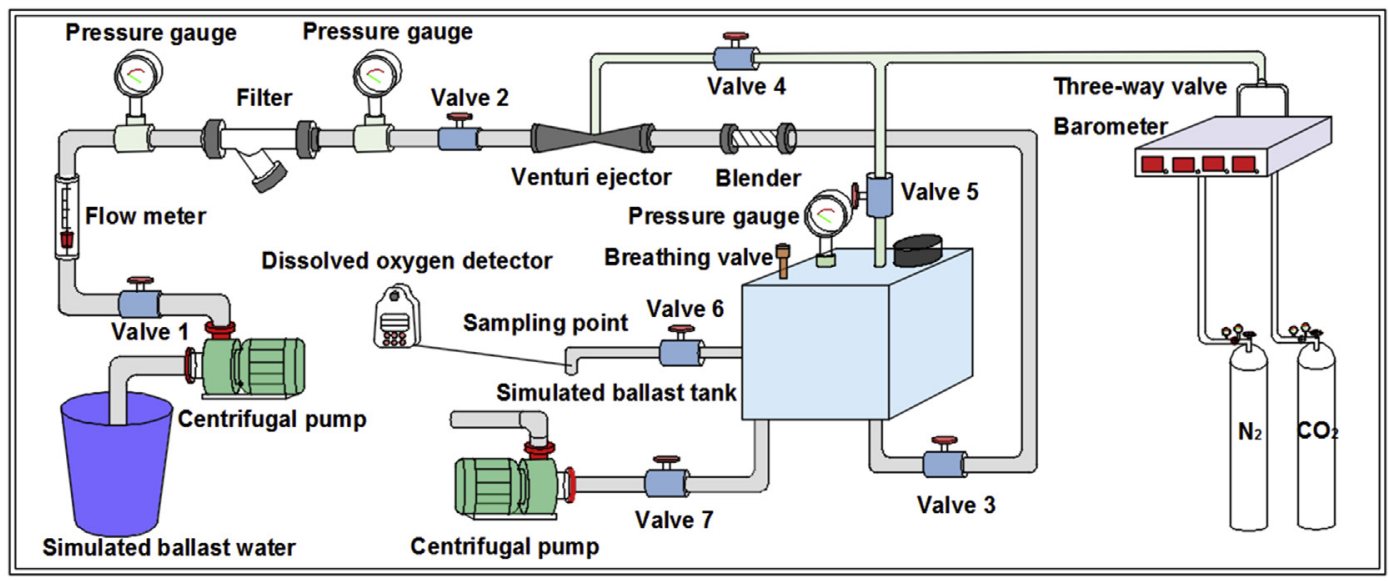

Fig.1. Flow chart of ballast water treatment system using inert flue gas.

the pressure indication of the ballast water tank and piping system were recorded at all time. The gas mass flow controller and the ballast water supply pump were immediately turned off when the water level of the ballast tank was lower than 100L from the start of the recording. All switches were also off around the ballast water tank. During the test period of $265 \mathrm{~h}$, the parameters of the treated ballast water were measured. They are temperature, salinity, $\mathrm{pH}$, dissolved oxygen (DO) concentration, turbidity, $\mathrm{NO}_{3}-\mathrm{N}, \mathrm{PO}_{4}-\mathrm{P}$, dissolved organic carbon (DOC) and particulate organic carbon (POC).

\section{Test principle and test simulation of ballast water preparation}

\subsection{Test principle}

During the test process, the gas flow rate and ballast water were adjusted by the seven-star gas flow meter in the venturi ejector. The inert flue gas formed gas cavitation in the ballast water, and mixed into the ballast tank. The gas cavitation absorbed dissolved oxygen in the ballast water which rose above the water surface under buoyancy. The ballast water maintained a low concentration of dissolved oxygen, and a slight positive pressure state.

\subsection{Test simulation of ballast water preparation}

In the course of the experiment, in view of the limited conditions for using seawater, the experiment was simulated by fresh water instead of seawater and cultivated the index plankton by comparing the parameters of ballast seawater, as shown in Table 1.

Sea salt and Sodium hydroxide was added to the water to adjust the salinity and $\mathrm{pH}$ value to meet seawater salinity and $\mathrm{pH}$ standards. The cultured indicator planktonic microorganisms of Chlorella sp. and $E$. coli were added to the prepared seawater, and after 1 hour, the dispersion was measured and the test was started. Firstly, pure water was added to a $2000 \mathrm{ml}$ Erlenmeyer flask, and a high density Chlorella sp. seed solution was added (the ratio of pure water to seed solution is $1: 1$, and the concentration of the seed solution was $5.2 \times 10^{4}$ cells $/ \mathrm{ml}$ ). The seed solution was added to the Chlorella medium, the mouth of the bottle was sealed, shaken and placed on the cultured rack (the ratio of seed solution and medium was 1:1). During the cultivation process, a lamp was used to simulate the sunlight, and the daily illumination time was 12 hours. The formulation of the medium of the 1L Chlorella stock solution is shown in Table 2. The total incubation time of the Chlorella stock solution was 21 days. The experimental simulation of E. coli stock solution in ballast water was provided by the Institute of Biology of Jiangsu University of Science and Technology. The concentration of $E$. coli was $1.2 \times$ $10^{4} \mathrm{cfu} / \mathrm{ml}$, and the experimental period was $265 \mathrm{~h}$.

\section{Experimental results}

\subsection{Effect of nitrogen on microbial lethality}

Fig. 2 shows the correlation between the concentration of dissolved oxygen and $\mathrm{N}_{2}$ in ballast water when the inert flue gas $\mathrm{N}_{2}$ and ballast water were mixed into the ballast tank through the venturi ejector. The experiment fitted and correlated the three sets of data. Fig. 3 shows the relationship

Table 1. The seawater parameter.

\begin{tabular}{lll}
\hline Temperature/C & Salinity/PSU & $\mathrm{pH}$ \\
\hline $25.5 \pm 0.9$ & $25.5-35.5$ & $8.39 \pm 0.27$ \\
\hline
\end{tabular}


Table 2. $1 \mathrm{~L}$ Chlorella stock solution medium formula.

\begin{tabular}{ll}
\hline Name & Content \\
\hline Sodium nitrate & $75 \mathrm{mg}$ \\
Sodium dihydrogen phosphate dihydrate & $5.65 \mathrm{mg}$ \\
Metal liquid & $1.0 \mathrm{ml}$ \\
Vitamin fluid & $1.0 \mathrm{ml}$ \\
Sodium silicate & $50 \mathrm{mg}$ \\
Pure water & $1000 \mathrm{ml}$ \\
\hline
\end{tabular}

between microbial lethality and dissolved oxygen concentration.

The concentration of nitrogen was inversely proportional to the concentration of dissolved oxygen in the ballast water (Fig. 2). As the nitrogen flux increased, the concentration of dissolved oxygen in

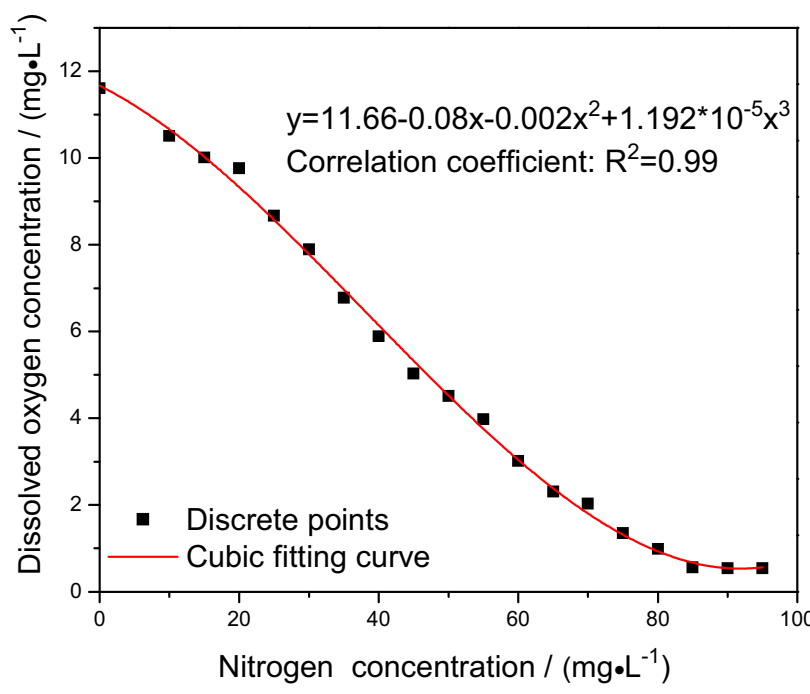

Fig. 2. Correlation between nitrogen concentration and dissolved oxygen.

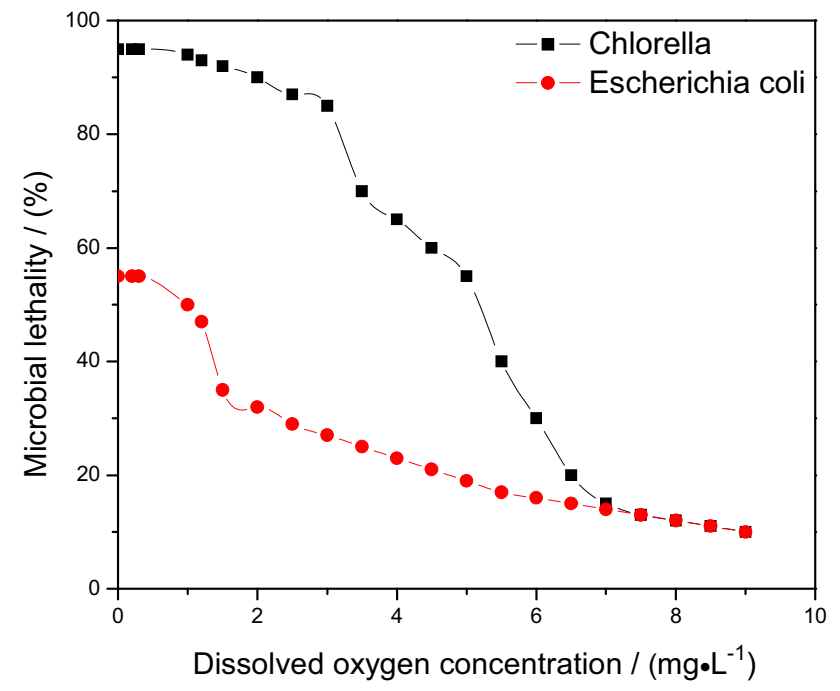

Fig. 3. Effect of dissolved oxygen concentration on microbial lethality. the ballast water decreased until it reached complete deoxygenation. Complete deoxygenation was achieved when the dissolved oxygen content was 0.3 $\mathrm{mg} / \mathrm{L}$. When nitrogen was supplied separately, the volume flow rate of the gas was $500 \mathrm{ml} / \mathrm{min}$.

The lethality of the microorganism was inversely proportional to the dissolved oxygen concentration (Fig. 3). When the dissolved oxygen concentration was lower, and the microbial lethality was higher. When the dissolved oxygen concentration was reduced from $9 \mathrm{mg} / \mathrm{L}$ to $0.5 \mathrm{mg} / \mathrm{L}$, the mortality of Chlorella sp. increased from $10 \%$ to $96 \%$, and the mortality of E. coli increased from $10 \%$ to $57.8 \%$. As the dissolved oxygen concentration continued to decrease, and the microbial mortality remained unchanged. At present, there is no absolute basis for the explanation of this phenomenon. The most likely reason is that the dissolved oxygen concentration is reduced, that causing some E. coli to die due to lack of oxygen. However, E. coli is a facultative anaerobic microorganisms, and some of them can still survive on anaerobic respiration in an anaerobic environment. Chlorella is an aerobic respiration type. The hypoxic state in ballast water causes chlorella to undergo anaerobic respiration, releasing alcohol and $\mathrm{CO}_{2}$, causing a large number of chlorella deaths.

In order to explore the functional relationship between microbial lethality and dissolved oxygen concentration after inert flue gas nitrogen treatment of ballast water, the test data was fitted to obtain a regression equation. Equation (4.1) is the fitted regression equation between the lethality of $E$. coli and the concentration of dissolved oxygen, subject to the exponential function relationship, and the Adj. R-Square of the curve is 0.98. Equation (4.2) is the fitted regression equation between the lethality of Chlorella sp. and dissolved oxygen concentration, which is subject to a 4th order polynomial function relationship, and the Adj. R-Square of the curve is 0.99 .

$y=25.61 \exp (-x / 3.261)+24.81 \exp (-x / 3.262)+7.64$

where: $\mathrm{x}$-the mass concentration of dissolved oxygen $/ \mathrm{mg} \cdot \mathrm{h}^{-1} ; \mathrm{y}$-the lethal rate of E. coli/\%.

$y=94.42+2.068 x-1.65 x^{2}-0.31 x^{3}+0.04 x^{4}$

where: $\mathrm{x}$-dissolved oxygen mass concentration/ $\mathrm{mg} \cdot \mathrm{h}^{-1} ; \mathrm{y}$-Chlorella lethality $/ \%$.

In this research, the fatality rate of chlorella with different dissolved oxygen concentrations was calculated by the mass concentration of dissolved 
oxygen according to the above formula, and the mass concentration of dissolved oxygen was related to nitrogen concentration.

In order to compare the influence factors of microbial mortality in ballast water after $\mathrm{N}_{2}$ treatment, the microbial living environment and microbial mortality of the control tank were given. Table 3 shows the relationship of dissolved oxygen, $\mathrm{pH}$, temperature of experimental tank and control tank during the $265 \mathrm{~h}$ test period. The dissolved oxygen concentration in the ballast water remained basically unchanged after $265 \mathrm{~h}$ and the remained at 0.5 $\mathrm{mg} / \mathrm{L}$, which indicated that the sealability of the ballast tank was good, and the microorganisms did not regenerate. The concentration of dissolved oxygen in the control tank fluctuated with time, which was higher than the experiment tank. The $\mathrm{pH}$ value of the experiment tank was lower than the control tank within the test range. The $\mathrm{pH}$ of the experiment tank and control tank decreased with time. Prior to $40 \mathrm{~h}$, the temperature of the control tank was lower than that of the experiment tank. After $40 \mathrm{~h}$, the temperature of the control tank was higher than that of the experiment tank.

The number of microbial survival in the experimental group reduced to some extent when compared with the control group (Fig. 4). The number of Chlorella sp. decreased with increase of treatment time compared with the control group. When the treatment time reached $125 \mathrm{~h}$, the mortality rate of Chlorella sp. reached $98.96 \%$, and remained basically unchanged. At $170 \mathrm{~h}$, the mortality rate of $E$. coli reached $71.67 \%$, and then became

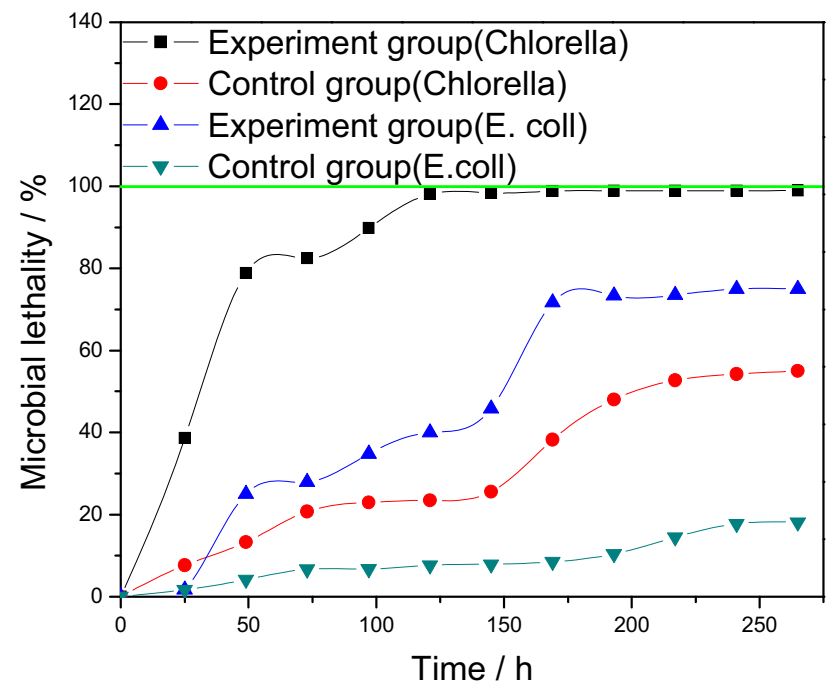

Fig. 4. Relationship curves between time and microbial lethality during $265 h$.

stationary. At 265 hours, the mortality rate of E. coli reached $75 \%$. The mortality of Chlorella in the experimental group and control group was higher than that of E. coli. Moreover, the number of deaths in E. coli and Chlorella is higher. At 265 hours, the mortality rate of Chlorella in the experiment tank was $47 \%$ of the control tank, and the mortality rate of $E$. coli in the experiment tank was $312 \%$ of the control tank.

The treatment tank and the control tank were made of stainless steel and sealed, and this poor living environment cause some microorganisms to die, but some survive [17]. In addition, the decline in

Table 3. Parameters variation of ballast water after $\mathrm{N}_{2}$ treatment in $265 \mathrm{~h}$ test period.

\begin{tabular}{|c|c|c|c|c|c|c|}
\hline \multirow[t]{2}{*}{ Time/h } & \multicolumn{2}{|c|}{ Temperature $/{ }^{\circ} \mathrm{C}$} & \multicolumn{2}{|l|}{$\mathrm{pH}$ value } & \multicolumn{2}{|c|}{ Dissolved oxygen/(mg/L) } \\
\hline & Experiment & Control & Experiment & Control & Experiment & Control \\
\hline 0 & 25.4 & 25.1 & 8.48 & 8.55 & 8.79 & 8.75 \\
\hline 1 & 23.4 & 24.2 & 8.34 & 8.45 & 0.56 & 8.98 \\
\hline 5 & 24.1 & 24.3 & 8.41 & 8.43 & 0.54 & 8.82 \\
\hline 18 & 25.4 & 25.2 & 8.42 & 8.57 & 0.55 & 8.6 \\
\hline 27 & 25.3 & 25.1 & 8.35 & 8.55 & 0.52 & 8.89 \\
\hline 42 & 25.2 & 25.4 & 8.28 & 8.49 & 0.53 & 8.52 \\
\hline 52 & 25.4 & 25.7 & 8.2 & 8.45 & 0.51 & 8.76 \\
\hline 66 & 23.3 & 23.5 & 8.31 & 8.41 & 0.54 & 8.69 \\
\hline 76 & 25.2 & 25.3 & 8.22 & 8.36 & 0.52 & 8.92 \\
\hline 90 & 24.2 & 24.3 & 8.3 & 8.46 & 0.51 & 9.23 \\
\hline 108 & 25.2 & 25.7 & 8.21 & 8.24 & 0.53 & 10.11 \\
\hline 138 & 25.1 & 25.5 & 8.23 & 8.37 & 0.52 & 10.03 \\
\hline 158 & 25.2 & 25.6 & 8.19 & 8.24 & 0.54 & 9.89 \\
\hline 181 & 25.1 & 25.8 & 8.21 & 8.31 & 0.56 & 9.68 \\
\hline 203 & 23.2 & 25.6 & 8.15 & 8.22 & 0.51 & 11.01 \\
\hline 213 & 25.1 & 25.7 & 8.14 & 8.24 & 0.52 & 10.89 \\
\hline 243 & 25 & 25.4 & 8.12 & 8.26 & 0.49 & 9.79 \\
\hline 255 & 24.1 & 24.6 & 8.12 & 8.23 & 0.52 & 9.89 \\
\hline 265 & 25 & 25.7 & 8.1 & 8.24 & 0.51 & 9.56 \\
\hline
\end{tabular}


the number of Chlorella in the control tank does not mean death, but rather prolongs survival in the form of spores in dark conditions [18]. In addition, Chlorella aerobic respiration released $\mathrm{CO}_{2}$ to lower the $\mathrm{pH}$ of the control tank. The dissolved oxygen in the treatment tank was significantly reduced, so that the microorganisms could not adapt to the sudden change of the hypoxic environment for a long time and caused a large number of deaths at the beginning of the test. Chlorella is an aerobic respiration organism. It was in a state of hypoxia for a long time, and it could not carry out photosynthesis in time to maintain life with anaerobic respiration. However, as time increased, alcohol and lactic acid produced by anaerobic respiration, as well as $\mathrm{CO}_{2}$, caused a decrease in the $\mathrm{pH}$ of the ballast water, worsening the living environment of the microorganisms, and chlorella died. In addition, as hypoxia increased with time, the interspecific competition between microorganisms increased that causing some death. However, some of $E$. coli survived in anoxic conditions. Tamburria et al. [15] studied the killing effect of $\mathrm{N}_{2}$ on Microbial after the dissolved oxygen in the ballast water was removed. The results showed that no organism survived in an oxygen-deficient environment for a long time. The results of this experiment agrees with this study, but E. coli is a facultative anaerobic microorganism, and some survived in an anaerobic environment.

\subsection{Effect of carbon dioxide on microbial lethality}

Although $\mathrm{CO}_{2}$ is an essential gas for the survival of green plants, a large amount of $\mathrm{CO}_{2}$ cause changes to the chemical environment for microorganisms. Therefore, it is necessary to study the lethality of microorganisms caused by $\mathrm{CO}_{2}$ treatment. When $\mathrm{CO}_{2}$ was supplied separately, the volume flow rate of the gas was $500 \mathrm{ml} / \mathrm{min}$. Fig. 5 shows the effect of $\mathrm{pH}$ on microbial lethality.

As the $\mathrm{PH}$ value increases, the lethality of the microorganism first increased and then decreased, and then rises again, and remains relatively stable. The effect of $\mathrm{CO}_{2}$ on E. coli was greater than that on chlorella. At $\mathrm{pH} 7.5$, E. coli had the lowest lethality, and at $\mathrm{pH}$ 6.5, chlorella had the lowest lethality. When the $\mathrm{pH}$ is 6 , the microbial mortality is significantly increased. At this time, the mortality rate of the chlorella reaches $55 \%$, and the mortality rate of the E. coli reaches $60 \%$. The reason is that as the $\mathrm{CO}_{2}$ concentration increases, part of the $\mathrm{CO}_{2}$ in the ballast tank overflows the ballast water and takes away some of the dissolved oxygen in the ballast water. In addition, a portion of the $\mathrm{CO}_{2}$ is

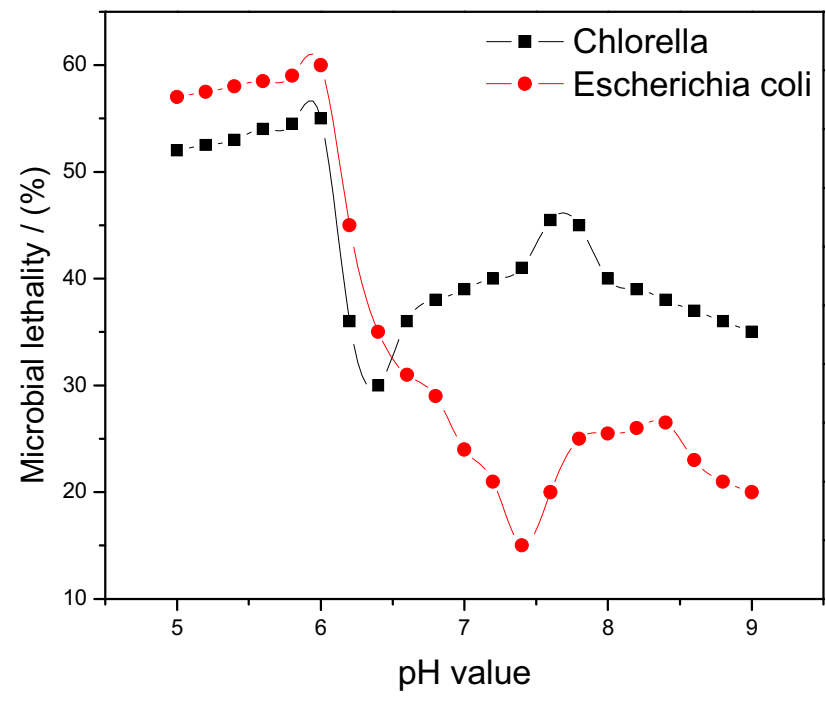

Fig. 5. Effect of $p H$ on microbial lethality.

dissolved in the ballast water to form carbonic acid so that the $\mathrm{pH}$ of the ballast water is reduced.

To further investigate the changes in microbial mortality after $\mathrm{CO}_{2}$ treatment, Table 4 shows the relationship between dissolved oxygen content, $\mathrm{pH}$ and temperature during the $265 \mathrm{~h}$ test period after $\mathrm{CO}_{2}$ treatment, respectively.

Table 4 shows that as time increases, the overall trend of dissolved oxygen concentration in the treatment tank decreases first then increases, and the dissolved oxygen concentration is higher than that of the control ballast tank. The $\mathrm{pH}$ value of the treatment tank is maintained at around 6, and the $\mathrm{pH}$ of the control tank fluctuates between 8.5 and 8.8. The temperature of the treatment process chamber and the temperature of the control chamber are in dynamic equilibrium.

As shown in Fig. 6, with the treatment time increases, the mortality of E. coli and chlorella increases, and the mortality rate of chlorella is higher than that of E. coli. Compared to the control tank, chlorella and E. coli in the experiment tank increased $22 \%$ and $230 \%$, respectively. In summary, the reason path is that although the photosynthesis of chlorella requires sunlight as a nutrient, the environment of the ballast tank cannot make chlorella work with photosynthesis. Chlorella and E. coli undergo aerobic respiration during the experiment. A large amount of $\mathrm{CO}_{2}$ will form an equilibrium system of $\mathrm{CO}_{2}, \mathrm{H}_{2} \mathrm{CO}_{3}, \mathrm{HCO}_{3}^{-}$and $\mathrm{CO}_{3}^{2-}$ in the ballast water, which will lower the $\mathrm{pH}$ value of the ballast water, causing hypercapnia of the microorganisms $[19,20]$. It can directly kill anaerobic microorganisms. In addition, chlorella and E. coli undergo aerobic respiration to release $\mathrm{CO}_{2}$, further 
Table 4. Parameter variation of ballast water after $\mathrm{CO}_{2}$ treatment in $265 \mathrm{~h}$ test period.

\begin{tabular}{|c|c|c|c|c|c|c|}
\hline \multirow[t]{2}{*}{ Time/h } & \multicolumn{2}{|c|}{ Temperature $/{ }^{\circ} \mathrm{C}$} & \multicolumn{2}{|l|}{$\mathrm{pH}$ value } & \multicolumn{2}{|c|}{ Dissolved oxygen/(mg/L) } \\
\hline & Experiment & Control & Experiment & Control & Experiment & Control \\
\hline 0 & 25.1 & 25.4 & 8.48 & 8.55 & 9.56 & 9.85 \\
\hline 1 & 24.6 & 25.1 & 6.05 & 8.68 & 9.89 & 10.08 \\
\hline 20 & 26.1 & 25.5 & 6.12 & 8.82 & 9.65 & 9.45 \\
\hline 46 & 26 & 25.8 & 6.15 & 8.5 & 9.23 & 9.56 \\
\hline 68 & 26.5 & 26.4 & 6.13 & 8.7 & 8.98 & 8.95 \\
\hline 92 & 25.5 & 25.8 & 6.14 & 8.61 & 8.82 & 9.23 \\
\hline 116 & 26.2 & 25.4 & 6.15 & 8.56 & 8.6 & 8.98 \\
\hline 146 & 25.3 & 25.6 & 6.12 & 8.54 & 8.89 & 9.08 \\
\hline 170 & 25.1 & 25.7 & 6.21 & 8.43 & 8.52 & 8.89 \\
\hline 193 & 26.1 & 25.9 & 6.11 & 8.61 & 8.76 & 8.69 \\
\hline 216 & 25.6 & 24.8 & 6.12 & 8.41 & 8.69 & 9.06 \\
\hline 239 & 24.8 & 24.9 & 6.1 & 8.43 & 8.92 & 9.58 \\
\hline 263 & 25.1 & 25.2 & 6.01 & 8.42 & 9.23 & 9.45 \\
\hline
\end{tabular}

aggravating the growth environment of microorganisms, causing death of chlorella and E. coli.

\subsection{Effect of $\mathrm{N}_{2}$ and $\mathrm{CO}_{2}$ on microbial lethality}

In order to simulate the effect of inert flue gas treatment on ballast watermore accurately and realistically, the test was carried out by mixing $\mathrm{N}_{2}$ and $\mathrm{CO}_{2}$ to treat ballast water. The supply volume ratio of $\mathrm{N}_{2}$ and $\mathrm{CO}_{2}$ is 7:1, the volume flow rate of $\mathrm{N}_{2}$ is $840 \mathrm{~mL} / \mathrm{min}$, and the volume flow rate of $\mathrm{CO}_{2}$ is $120 \mathrm{~mL} / \mathrm{min}$. Fig. 7 shows the relationship between microbial lethality as a function of $\mathrm{pH}$ and dissolved oxygen concentration. Fig. 8 shows the relationship between the lethality rate of planktonic microorganism and time during the $265 \mathrm{~h}$ test period.

It can be seen from Fig. 7 that when the dissolved oxygen concentration is constant, the $\mathrm{pH}$ is equal to

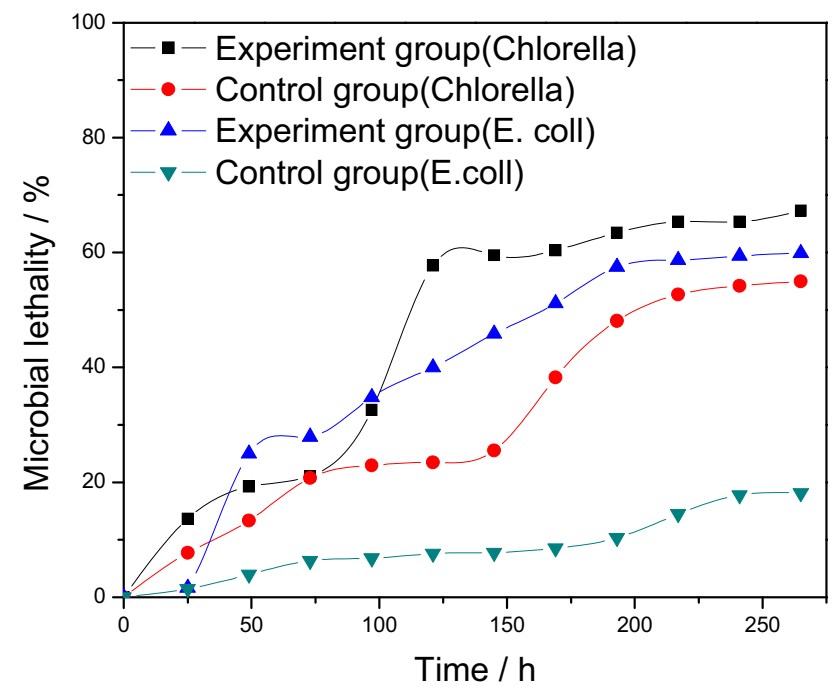

Fig. 6. Relationship curves between time and microbial lethality during $265 h$.
6 , and the microbial lethality is the best. When the $\mathrm{pH}$ is less than 6 , the microbial lethality remains substantially unchanged. When the $\mathrm{pH}$ value is constant, the microbial lethality is higher with the dissolved oxygen concentration lower. Under the test conditions, the dissolved oxygen concentration reaches $0.5 \mathrm{mg} / \mathrm{L}$, and the microbial lethality is the best. Therefore, when the $\mathrm{pH}$ value is 6 and the dissolved oxygen concentration is $0.5 \mathrm{mg} / \mathrm{L}$, the microbial lethality rate is the highest, reaching $99.97 \%$. Continued reduction of $\mathrm{pH}$ at this time has little effect on the lethality of microorganisms and remains essentially unchanged. It can be seen from Fig. 8 that at $100 \mathrm{~h}$, almost all of the chlorella died, and at $175 \mathrm{~h}$, almost all of the E. coli died, and no regeneration occurred in the subsequent time. The mortality rates of chlorella and E. coli in the

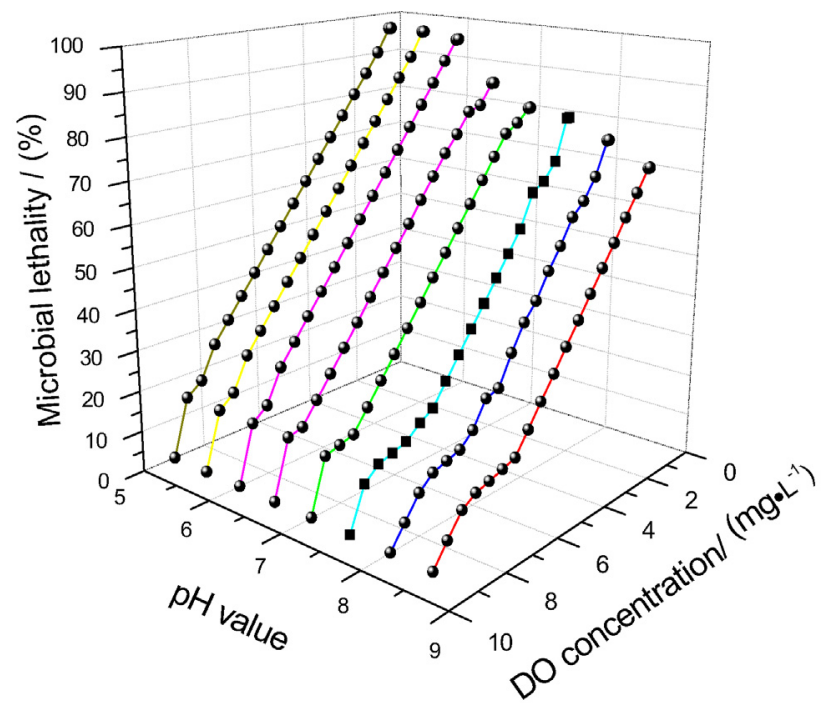

Fig. 7. Relationship between microbial lethality and $\mathrm{pH}$ and dissolved oxygen. 


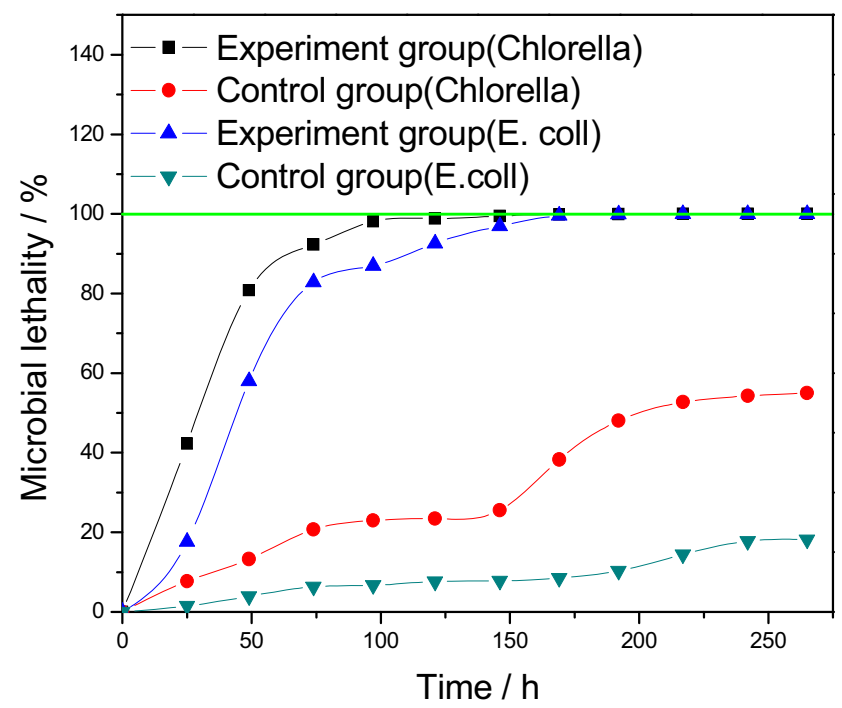

Fig. 8. Relationship between microbial lethality and time.

treatment tank reached $99.99 \%$ and $99.98 \%$, respectively, which was significantly higher than that in the control tank. The reason is mainly that because of the inert flue gas mixture with $\mathrm{N}_{2}$ and $\mathrm{CO}_{2}$ and ballast water are formed in the venturi ejector, forming a cavitation, part of the cavitation overflow process absorbs dissolved oxygen in the water, and a part of $\mathrm{CO}_{2}$ is dissolved in the ballast water. The dissolved oxygen concentration in the ballast water is lowered and acidic, so that the microbial living environment has a significant amount of deterioration. Microorganisms perform anaerobic respiration in the treatment tank, and the release of $\mathrm{C}_{2} \mathrm{H}_{5} \mathrm{OH}$, $\mathrm{CO}_{2}$ and $\mathrm{C}_{3} \mathrm{H}_{6} \mathrm{O}_{3}$ further deteriorates their living environment, leading to the death of chlorella and E. coli due to the inability to absorb nutrient absorption from ballast water in time. In addition, light limitation, bruising during ballast [16], also caused the death of some microorganisms.

\subsection{Effect of nitrogen and carbon dioxide on water quality}

Seawater quality is an important factor affecting the growth and reproduction of microorganisms in aquatic environments. The treatment of ballast water is to prevent biological invasion and damage the ecological environment, in line with the D-2 standard. In order to prevent secondary pollution of the treated ballast water, the ballast water parameter treated by inertial flue gas were tested and analyzed after the experiment, and compared with seawater, as shown in Table 5.
It can be seen from Table 5 that the dissolved oxygen concentration is $0.5 \mathrm{mg} / \mathrm{L}$, and $\mathrm{pH}$ value is 6.0. According to the water quality test indicators in the control and treatment tank, there is no significant change in temperature and salinity. The concentrations of nitrate $\left(\mathrm{NO}_{3}-\mathrm{N}\right)$ and phosphate $\left(\mathrm{PO}_{4}-\mathrm{P}\right)$ in the nutrients were tested, and the treatment of inert flue gas had no significant effect on the nutrient concentration in the simulated water. According to the requirements of G8 Guideline, in terms of evaluating ballast water management system (BWMS) performance, the dissolved organic carbon (DOC) concentration is lower than the recommended minimum concentration of $5 \mathrm{mg} / \mathrm{L}$. The particulate organic carbon (POC) has an effect on DOC concentration due to reaction with the active substance. The POC value is $0.3 \%$ higher than the standard value.

\section{Conclusion}

The experiment examined the microbial mortality after treatment of ballast water with inert flue gas. The ballast water was simulated by culturing the indicator microorganisms chlorella and $\mathrm{E}$. coli, and the inert flue gas was simulated by $\mathrm{N}_{2}$ and $\mathrm{CO}_{2}$. The test period is $265 \mathrm{~h}$. Within the scope of the test, this paper draws the following conclusions.

(1) Using $\mathrm{N}_{2}$ to treat ballast water can reduce the dissolved oxygen concentration in the ballast water, and the micro-positive pressure in the ballast tank causes the microorganism to die due to the lack of oxygen necessary for growth. Compared to the control tank, the mortality of chlorella and $\mathrm{E}$. coli in the treatment tank is increased by $47 \%$ and $312 \%$, respectively.

(2) After $\mathrm{CO}_{2}$ treatment, the $\mathrm{pH}$ value of ballast water is significantly reduced. In addition, the aerobic respiration of microorganisms further reduces the $\mathrm{pH}$ value of the ballast tank, the acidic environment increases the mortality of chlorella, and a large number of E. coli died because of the hypercapnia. The dissolved oxygen concentration in the ballast water is $0.5 \mathrm{mg} /$ $\mathrm{L}$, and the $\mathrm{pH}$ value is 6 , which has the best killing effect on microorganisms. The mortality of chlorella and E. coli in the treatment tank increased by $22 \%$ and $230 \%$, respectively, compared to the control tank.

(3) After $\mathrm{N}_{2}$ and $\mathrm{CO}_{2}$ treatment, the ballast water environment is in low dissolved oxygen concentration and acidic environment, causing a large number of microbial death, the mortality 
Table 5. Changes in simulated seawater quality parameters before and after inert flue gas treatment.

\begin{tabular}{lllllllll}
\hline parameter & Temperature/C & salinity/PSU & $\mathrm{pH}$ & $\begin{array}{l}\mathrm{DO} \\
/ \mathrm{mg} \cdot \mathrm{L}^{-1}\end{array}$ & $\mathrm{NO}_{3}-\mathrm{N} / \mathrm{mg} \cdot \mathrm{L}^{-1}$ & $\begin{array}{l}\mathrm{PO}_{4}-\mathrm{P} \\
/ \mathrm{mg} \cdot \mathrm{L}^{-1}\end{array}$ & $\mathrm{DOC} / \mathrm{mg}-\mathrm{C} \cdot \mathrm{L}^{-1}$ & $\mathrm{POC} / \mathrm{mg} \cdot \mathrm{L}^{-1}$ \\
\hline Initial value & 25.21 & 31.5 & 8.51 & 9.54 & 0.003 & 0.076 & 2.1 & 2.3 \\
Control group & 25.02 & 31.2 & 8.45 & 9.46 & 0.018 & 0.016 & 2.0 & 2.7 \\
Experimental group & 25.14 & 32.5 & 6.02 & 0.51 & 0.03 & 0.046 & 1.9 & 2.2 \\
\hline
\end{tabular}

rate of chlorella reaches $99.99 \%$, and the mortality rate of E. coli reaches $99.98 \%$.

(4) The ballast water after inert flue gas treatment was analyzed, and the dissolved organic carbon concentration was lower than the recommended minimum concentration of $5 \mathrm{mg} / \mathrm{L}$. The particulate organic carbon had an effect on DOC concentration due to reaction with the active substance. Compared with DOC, the value of POC is higher than the standard value of $0.3 \%$.

\section{Acknowledgment}

The work was funded by Jiangsu Science and Technology Forward-looking Joint Research Project (BY2015065-10).

\section{References}

[1] Erga OKH, Andrés JM, Enger Ø, Vadstein O. Microorganisms in ballastwater: Disinfection, community dynamics, and implications for management. Sci Total Environ 2019;657(50): 704-16.

[2] Lauridsen FS, Drillet G, Hansen FT, Saunders J. Same Risk Area: An area-based approach for the management of bioinvasion risks from ships' ballast water. Mar Pol 2018;97(2): 147-55.

[3] Cohen AN, Dobbs FC, Chapman PM. Revisiting the basis for US ballast water regulations. Mar Pollut Bull 2017;118(1-2): 348-53.

[4] Guilbaud J, Massé A, Wolff FC, Jaouen P. Porous membranes for ballast water treatment from microalgae-rich seawater. Mar Pollut Bull 2015;101(2):612-7.

[5] Ghods NN, Ghadiri M, Früh WG. Management and environmental risk study of the physicochemical parameters of ballast water. Mar Pollut Bull 2017;114(1):428-38.

[6] Bradie J, Gianoli C, He JJ, Curto AL, Stehouwer P, Veldhuis M, Welschmeyer N, Younan L, Zaake A, Bailey S. Detection of UV-treatment effects on plankton by rapid analytic tools for ballast water compliance monitoring immediately following treatment. J Sea Res 2018;133(1):177-84.
[7] Perrins JC, Cordell JR, Ferm NC, Grocock JL, Herwig RP. Mesocosm experiments for evaluating the biological efficacy of ozone treatment of marine ballast water. Mar Pollut Bull 2006;52(12):1756-67.

[8] Zhang YQ, Zuo SJ, Zhang Y, Li M, Cai and JJ, Zhou MH. Disinfection of simulated ballast water by a flow-through electro-peroxone process. Chem Eng J 2018;348:485-93.

[9] Delacroix S, Vogelsang C, Tobiesen A, Liltved H. Disinfection by-products and ecotoxicity of ballast water after oxidative treatment - Results and experiences from seven years of full-scale testing of ballast water management systems. Mar Pollut Bull 2013;73(1):24-36.

[10] Zhang N, Ma B, Li JX, Zhang ZT. Factors affecting formation of chemical by-products during ballast water treatment based on an advanced oxidation process. Chem Eng J 2013; 231(2):427-33.

[11] Grob C, Pollet BG. Regrowth in ship's ballast water tanks: Think again! Mar Pollut Bull 2016;109(1):46-8.

[12] McCollin T, Badia GQ, Josefsen KD, Gill ME, Mesbahi E, Frid CLJ. Ship board testing of a deoxygenation ballast water treatment. Mar Pollut Bull 2007;54(8):1170-8.

[13] Lafontaine Y, Chambers Y, Despatie SP, Gagnon C, Blaise C. Effectiveness and potential environmental impact of a yeastbased deoxygenation process for treating ship ballast waters. Water Qual Res J Can 2013;48(1):55-75.

[14] Lafontaine Y, Despatie SP. Despatie, Performance of a biological deoxygenation process for ships' ballast water treatment under very cold water conditions. Sci Total Environ 2014;472(15):1036-43.

[15] Tamburria MN, Wasson K, Matsuda M. Ballast water deoxygenation can prevent aquatic introductions while reducing ship corrosion. Biol Conserv 2002;103(3):331-41.

[16] Pecarevic M, Mikus J, Prusina I, Juretic H, Cetinic AB, Brailo M. New role of hydrocyclone in ballast water treatment. J Clean Prod 2018;188(1):339-46.

[17] Kerr S. Ballast water ports and shipping study.Austeralian Quarantine and Inspection Service. Ballast Water Research Series. 1994. Report No.5.

[18] Jochen F. Dark survival strategies in marine phytoplankton assessed by cytometric measurement of metabolic acticity with fluorescein diacetate. Mar Biol 1999;135(4):721-8.

[19] Moreira A, Figueira E, Pecora IL, Soares AMVM, Freitas R. Native and exotic oysters in Brazil: Comparative tolerance to hypercapnia. Environ Res 2018;161(2):202-11.

[20] Hvas M, Damsgaard C, Gam LTH, Huong DTT, Jensen FB, Bayley M. The effect of environmental hypercapnia and size on nitrite toxicity in the striped catfish (Pangasianodon hypophthalmus). Aquat Toxicol 2016;176(1):151-60. 